11 FOOD SENSITIVITY AND THE NEPHROTIC SYNDROME INCLUDING MEMBRANOUS GLOMERULOPATHY. Douglas H. SAndberg, Dept. of Pediatrics, UnIntosh, Charles W. Bernsteln, Jose Strauss University of Colorado, Denver, Colorado.

We have reported previously that sensitivity to foods played an important role in six children with frequently relapsing sterold sensitive minimal change nephrotic syndrome (Lancet, in press). These investigations have been extended to include 4 more children with the same disorder and to 2 children, a 15-yrold WM and 13-yr-old WF with membranous glomerulopathy and the nephrotic syndrome. The latter two patients had not recelved prednisone. Evaluation of use of food extract injections for diagnostic testing and therapy also was performed. All patients, off prednisone, were admitted to the cilnical Research Center for tudy. All patients showed decrease in $24 \mathrm{hr}$. protein excretion on restricted diets, exacerbation of proteinuria with ingestion of apecific foods and decreased proteinuria with return to the previous limited diet. Oral challenge with milk produced alteration of plasme $\mathrm{C} 3$ in 6 of 7 patients. Seriel measurements of serum proteins and immunoglobulins were also made. Two patients were egetn glven milk and af ter onset of protelnurie, were tested intradermaliy with serial dilutions of milk extract. A treatment dose was determined and given daily s.q. While ingestion of milk continued. Th1s produced rapid decrease in protelnuria toward normal amounts. Subsequently these patients and 3 previous patients have been treated with food extract injection therapy with improved control of their nephrosis.

\section{PRESSURE NATRIURESIS IN EXPERIMENTAL GLOMERUIO} 1112 NEPHRITIS. Robert G. Schacht M. Sallad Igbal, Gerald Schulman and David S. Baldwin. New York University Schl. of Med. Depts. of Med. and Ped. New York, N.Y. (Spon. by J. Dancis). To examine possible adaptive mechanisms involved in the maintenance of glomerular filtration and sodium balance in glomerulonephritis, an in situ perfused kidney was compared in 7 normal mongrels $(\mathrm{N})$ and in 6 mongrels 2 to 4 months following the production of mild anti glomerular basement membrane nephritis (GN). The left kidney was perfused via a carotid-renal artery pump at systemic pressure levels and then at an elevated piessure. The average mean systemlc pressure was higher in GN $(140 \mathrm{~mm} \mathrm{Hg})$ than in $\mathrm{N}(121 \mathrm{~mm} \mathrm{Hg}$ ). Flltration rates (GFR) and renal plasma flows (RPF) were simllar, averaging 17.3 and $88 \mathrm{ml} / \mathrm{min}$ in $\mathrm{GN}$ and 18.6 and $70.3 \mathrm{ml} / \mathrm{min} \mathrm{in} \mathrm{N}$. When perfusion pressure was elevated to $195 \mathrm{~mm}$ Hg mean sodium excretion more than doubled in GN and in $N$ while GFR and RPF decreased by $30 \%$ in GN and remained constant in $\mathrm{N}$. The data demonstrate that pressure natriuresis occurs in GN as well as in $\mathrm{N}$ and that the GN kidney responds to Increased perfusion pressure with exaggerated vasoconstriction as compared to $\mathrm{N}$ which autoregulates. The excessive vasoconstrictor response of the GN kidney may be revealing an adaptive vasodilatation which occurs as a mechanism for the maintenance of renal perfusion and sodium homeostasts.

\section{4}

LATE METABOLIC ACIDOSIS (LMA): A REASSESSMENT mann, Jre and Adrian Spitzer Albert Einstein College of Weportment of Pediatrics, Bronx, New York.

There is substantial controversy regarding the definition and the clinical consequences of LMA. Well, low birth woight (LBW) infants fed standard formula were screened for blood $+\mathrm{CO}_{2}$ q. 3-4 days, $(n=114)$. Values for the entire group were normally distributed $(19.1 \pm 2.6$ (SD) mmol/l). From $1-21$ days of age the moan rose linearly from 18.2 to $19.7 \mathrm{mmol} / \mathrm{l}$ and then plateaved. 16/74 infants had "acidosis" orbitrarily defined as $+\mathrm{CO}_{2}$ $<18 \mathrm{mmol} / \mathrm{I}$. Eight of them were matched for maturity and weight and randomly allocated to treatment either with $5 \% \mathrm{NaHCO}_{3}$ p.o. to raise $1 \mathrm{CO}$ to $>21 \mathrm{mmol} / /$ (E) or $0.9 \% \mathrm{NaCl}$ (1 ml/feed) (C). The weight gain was $16.0 \pm 3.8$ (SE) $g / \mathrm{kg} /$ day in $E_{1} 17.2 \pm 1.4$ in $C_{i}(p>.7)$, and $14.4 \pm 1.21$ in non-acidotic babies. Values for titratable acidity, ammonium excretion, net acid excretion (NAE) or minimum urinary pH attained during ammonium chloride loading were not different in E or $C$ and were similar to those previously reported for non-acidotic infants. Thus: a) values of $\mathrm{CCO}_{2}$ as low as $14 \mathrm{mmol} / \mathrm{I}$ during the first month of life fall within 2 SD for age and cannot be considered abnormal; b) the appropriate NAE for age suggests that blood $\mathrm{HCO}_{2}$ in LBW infants reflects their $\mathrm{HCO}_{3}$ threshold; c) LMA did not rosult in an increased capacity to excrete $\mathrm{H}^{+}$; d) since no association was found between weight gain and $+\mathrm{CO}_{2}$, the failure to thrive of $\mathrm{LBW}$ infants might bo spuriously attributed to low $\mathrm{HCO}_{2}$.
PENAI BLOOD FLOW AND GLOMERULAR PERFUSION DURING URETERAL OCCLUSTON. Norman J. Siegel, Sonia Gunstream, Michael Kashgarian. Depts. Of Ped. S Path. 1115 Gunstream, Michael Kashgartan.

Although previous studies suggested that decreased cortical perfusion occurred in obstructive nephropathy, technical 1 imitations had prevented the measurement of renal blood flow (RBF) and glomerular perfusion during complete ureteral occlusion in the rat. Uaing a recent modification of the radioactive microsphere technique for the determination of RBP and Damadian's method for the determination of glomerular counts, both of these parameters were measured after $24 \mathrm{hrs}$ of bilateral ureteral occlusion and after sham operation. In sham operated control animals (n-10), RBF was 5.468 $\pm 0.241 \mathrm{ml} / \mathrm{min} / 100 \mathrm{gmBW}$ (Mean $\pm \mathrm{SEM}$ ), and glomerular perfusion in the superficial cortex (SNGP) was $225.8 \pm 9.7 \mathrm{n} 1 / \mathrm{m} 1 \mathrm{n}$; while in the deep cortex, glomerular perfusion (DNGP) was $199.7 \pm$ $10.0 \mathrm{n} 1 / \mathrm{mln}$. After $24 \mathrm{hrs}$ of ureteral occlusion $(\mathrm{n}-9)$, RBP had failen $57 \%$ to $3.120 \pm 0.274 \mathrm{ml} / \mathrm{min} / 100 \mathrm{gmBW}(\mathrm{P}<0.001)$. SNGP was only $85.1 \pm 6.7 \mathrm{nl} / \mathrm{mln}$ and DNGP was $112.7 \pm 8.2 \mathrm{nl} / \mathrm{mln}, 38 \%$ and $56 \%$ of control values, respectively, ( $P<0.001$ for both)

These data demonstrate that after $24 \mathrm{hrs}$ of ureteral occlusion a) total renal blood flow is markedly reduced, b) glomerular perfusion in the superficial cortex 18 even more strikingly dimin1shed, and c) the glomeruli in the deep cortex are comparatively better perfused than those in the superficlal cortex. These findings would support the hypothesis that cortical ischemia and glomerular hypoperfusion contribute to the renal infury in obstructive nephropathy.

116 SEQUENTIAL HISTOLOGIC CHANGES IN UNTREATED MESANGIAL1116 CAPILLARY GLOMERULONEPHRITIS (MCGN). Norman J. S1ege1, and Michael Kashgarian, Depts. of Ped. Path., Yale School of Medicine, New Haven, Conn.

Since recent data have suggested that h1stologic 1mprovement In MCGN may be associated with longterm sterold therapy, 4 patients with well documented MCGN who had not recelved sterolds or 1mmunosuppressive agents were studied. A second renal biopsy (bx) was performed $3,3,4$, and 5 years after the initial diagnosis (1st $\mathrm{bx}$ ). On the 1st $\mathrm{bx}$, all patients had diffuse mesang1al proliferation, lobulation, and splitting of the basement membrane: one patient hed subendothellal deposits, one patient had no deposits, and 2 patients had mesangial/subepithellal deposits.

On the second $b x$, there were progressive changes only in the one patient with subendothelial deposits (i.e., increased proliferation and nodular sclerosis). In the other 3 patients, there were elther no significant changes (one patient) or a decrease in the degree of mesanglal hypercellularity/prollferation (2 patients). Interst1t1al fibrosis and mesangial sclerosis were seen on the 2 nd $b x$ in all 4 patients.

These data suggest that renal histologic improvement (1.e., decreased cellularity/proliferation) may occur in patients wit MCGN who are untreated. However, the presence of interstitial fibrosis and mesanglal sclerosis suggests that some frreversible changes have occurred. 